UDC: 547.625

\title{
CO(II), NI(II), ZN(II) AND CU(II) COMPLEXES WITH N,N'-bis-(2-HYDROXYBENZYL)BENZIDINE
}

\author{
S.Z.Ismayilova \\ M.Nagiyev Institute of Catalysis and Inorganic Chemistry NAS of Azerbaijan \\ sabina.chemstry.1986@mail.ru
}

Received 20.05.2019

\begin{abstract}
New binuclear complexes $\mathrm{Co}(\mathrm{II}), \mathrm{Ni}(\mathrm{II}), \mathrm{Zn}(\mathrm{II})$ and $\mathrm{Cu}(\mathrm{II})$ with reduced Schiff's base were synthesized. The ligand was obtained by condensation of salicylaldehyde and benzidine at 2:1 molar ratio with following reducing by sodium borohydride. The composition and structure of the obtained complexes were studied by IR, electron spectroscopy, derivatography and elemental analysis.
\end{abstract}

Keywords: salicylaldehyde, benzidine, Schiff base, metal complexes.

doi:

\section{Introduction}

The multipurpose Schiff bases present universal series of the ligands capable to connect of the transition metals ions and to generate complexes with suitable properties for theoretical researches or practical use. Therefore area of the research of complexes with the multidentate Schiff bases derivatives of aromatic amines and carbonyl compounds gained considerable development in view of their structural variety, universal types binding and perspective bioactive properties [1]. Among them there are complexes with tetradentate Schiff's bases, are capable to connect reversibly oxygen [2], to catalyze a number of reactions, such as oxidation of organic compounds [3-10], hydrogenation [10, 11], oxidation of DNA [12-15] the some of other processes [10].

Complexes with such ligands are also models of some metal enzymes participating in biological redox processes, such as dioxygen activation [16], decomposition of hydrogen peroxide $[17,18]$ and in hydrolytic processes $[19,20]$. At the same time in literature there were no publications on the metal complexes with reduced tetradentate schiff bases.

In this work we received N,N'-bis(2-hydroxybenzyl)benzidine, its transition metal complexes and their structure and properties is studied.

\section{Experimental part}

\section{Materials and methods}

All chemicals and reagents were brands pure for chemical analysis and were used without any additional cleaning. IR spectrums were obtained on the Nicolet IS10 spectrophotometer, electronic absorbtion spectrum on the UVVIS Evolution 60S spectrophotometer, the thermogravimetric analysis was carried out with use of a derivatograph of NETZSCH STA 449F3, elemental analyzes were performed in the analytical laboratory Tubitak, Ankara, on the analyzer LECOCHNS 932.

\section{Preparation of the reduced Schiff base}

Schiff base $\left(\mathrm{H}_{2} \mathrm{~L}\right)$ was synthesized by known method [21]. The reduced Schiff base $\mathrm{H}_{2} \mathrm{~L}^{1}$ (Figure 1) was obtained as follows: $5 \mathrm{~g}$ $(0.01 \mathrm{M}) \mathrm{H}_{2} \mathrm{~L}$ was dissolved in a mixture of DMF and ethyl alcohol in 1:1 volume ratio $\mathrm{NaBH}_{4}$ was added with small amounts by mixing on magnetic stirring. At the end of reduction, the reaction solution was acidified with $10 \% \mathrm{HCl}$ solution to $\mathrm{pH}=7.5$ and left for crystallization in the refrigerated. A day later, the precipitated white polycrystalline product was filtered, washed with ethyl alcohol and dried in air. Yield $-4.35 \mathrm{~g} 87 \%$; m.p. $-210^{\circ} \mathrm{C}$, molecular weight $-398.50 \mathrm{~g} / \mathrm{mol}$. Calculated for $\mathrm{C}_{26} \mathrm{H}_{26} \mathrm{~N}_{2} \mathrm{O}_{2}$ (\%): C 79.58, H 5.15, N 7.13, O 8.14. Found (\%): C 75.58, H 5.13, N 7.15.

Synthesis of metal complexes. Cobalt(II), nickel(II), copper(II) and zinc(II) complexes with N,N'-bis-(2-hydroxybenzyl)benzidine $\left(\mathrm{H}_{2} \mathrm{~L}^{1}\right)$ were synthesized by mixing solutions of 0.010 mol metal acetate in $30 \mathrm{ml}$ methanol and 0.005 mole $\mathrm{H}_{2} \mathrm{~L}^{1}$ in $25 \mathrm{ml}$ hot dimethylformamide. The Ni(II) and $\mathrm{Zn}(\mathrm{II})$ complexes were obtained as insoluble precipitates after refluxing the reac- 
tion mixture for $2-3 \mathrm{~h}$, whereas the $\mathrm{Co}$ (II) and $\mathrm{Cu}$ (II) complexes dropped immediately at mixture solutions of metal salts and ligand. The powdery complexes were filtered, washed several times with ethanol and dried in air at room temperature. Below are the characteristics of the obtained complexes.

Complex $\left.\left[\mathrm{Cu}_{2} \mathrm{~L}^{\prime} \mathrm{CH}_{3} \mathrm{COO}\right)_{2}\left(\mathrm{H}_{2} \mathrm{O}\right)_{2}\right](1)$. Dark brown crystals with M.p. $>250^{\circ} \mathrm{C}$. Calculated for $\mathrm{C}_{30} \mathrm{H}_{32} \mathrm{Cu}_{2} \mathrm{~N}_{2} \mathrm{O}_{8}$ (\%): C 53.33, $\mathrm{H} \mathrm{4.77,}$ $\mathrm{N} 4.15, \mathrm{Cu}$ 18.80. Found (\%): C 53.31, H 4.78, $\mathrm{N} 4.13, \mathrm{Cu}$ 18.83. Main IR peaks (Vaseline, $\mathrm{cm}^{-}$ $\left.{ }^{1}\right)$ : $1598(\mathrm{C}-\mathrm{N}), 499(\mathrm{Cu}-\mathrm{N}), 1261(\mathrm{C}-\mathrm{O})$, $3402\left(v \mathrm{H}_{2} \mathrm{O}\right), 572(\mathrm{Cu}-\mathrm{O})$.

Complex $\left[\mathrm{Co}_{2} \mathrm{~L}_{2}{ }_{2}\right]$ (2). Brown powder with m.p. $>250^{\circ} \mathrm{C}$. Calculated for $\mathrm{C}_{52} \mathrm{H}_{44} \mathrm{Co}_{2} \mathrm{~N}_{4} \mathrm{O}_{4}$ (\%): C 68.87, H 4.89, N 6.18, Co 12.99. Found (\%): C 68.86, H 4.90, N 6.20, Co 12.97. Main IR peaks (Vaseline, $\left.\mathrm{cm}^{-1}\right): 1596(\mathrm{C}-\mathrm{N}), 487(\mathrm{Co}-\mathrm{N})$, $1258(\mathrm{C}-\mathrm{O}), 3402\left(v_{2} \mathrm{H}\right), 580(\mathrm{Co}-\mathrm{O})$.

Complex $\left[\mathrm{Ni}_{2} \mathrm{~L}_{2}{ }_{2}\right](3)$. Yellow crystalline powder with m.p. $>250^{\circ} \mathrm{C}$. Calculated for $\mathrm{C}_{52} \mathrm{H}_{44} \mathrm{Ni}_{2} \mathrm{~N}_{4} \mathrm{O}_{4}(\%)$ : C 68.86, H 4.89, N 6.19, Ni 12.98. Found (\%): C 68.84, H 4.90, N 6.18, Ni 12.99. Main IR peaks (Vaseline, $\mathrm{cm}^{-1}$ ): 1589 $(\mathrm{C}-\mathrm{N}), 491(\mathrm{Ni}-\mathrm{N}), 1264(\mathrm{C}-\mathrm{O}), 3402\left(\mathrm{v} \mathrm{H}_{2} \mathrm{O}\right)$, $586(\mathrm{Ni}-\mathrm{O})$.

Complex $\left[\mathbf{Z n}_{2} \mathbf{L}_{2}{ }_{2}\right]$ (4). Light yellow powder with m.p. $>250^{\circ} \mathrm{C}$. Calculated for $\mathrm{C}_{52} \mathrm{H}_{44} \mathrm{Zn}_{2} \mathrm{~N}_{4} \mathrm{O}_{4}$ (\%): C 67.91, H 4.82, N 6.09, Zn 14.21. Found (\%): C 67.89, H 4.83, N 6.10, Zn 14.19. Main IR peaks (Vaseline, $\left.\mathrm{cm}^{-1}\right): 1593$ $(\mathrm{C}-\mathrm{N}), 495(\mathrm{Zn}-\mathrm{N}), 1259(\mathrm{C}-\mathrm{O}), 3402\left(\mathrm{v} \mathrm{H}_{2} \mathrm{O}\right)$, $574(\mathrm{Zn}-\mathrm{O})$.

\section{Results and discussion}

The complexes are insoluble in water and in common organic solvents, such as ethanol, methanol, acetone, chloroform, benzene, diethyl ether, but dissolved in dimethylformamide and dimethylsulfoxide. The structures of the complexes were established using elemental analysis, IR, ESR and UV-visible spectra, thermogravimetric analysis (TGA), as well as their magnetic susceptibilities.

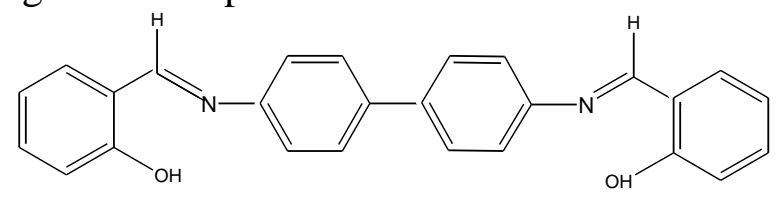

$\mathrm{LH}_{2}$

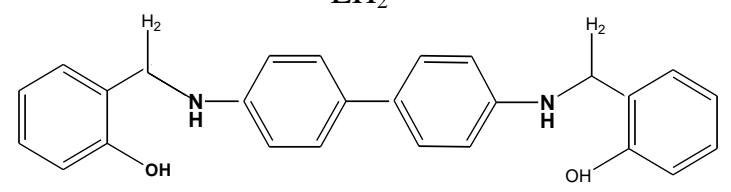

$\mathrm{L'H}_{2}$

Fig. 1. Structure of Schiff base $\mathrm{H}_{2} \mathrm{~L}$ and reduced Schiff base $\mathrm{H}_{2} \mathrm{~L}^{\prime}$.

\section{Characterization of complexes}

IR spectra. In IR spectrum of the Schiff base $\left(\mathrm{LH}_{2}\right)$ band absorption of azomethine bond $\mathrm{C}=\mathrm{N}$ are observed at $1620 \mathrm{~cm}^{-1}$, which is absent in IR spectrum of the reduced $\mathrm{L}^{1} \mathrm{H}_{2}$. The band absorption secondary $\mathrm{N}-\mathrm{H}$ group in the reduced schiffbase $\mathrm{L}^{1} \mathrm{H}_{2}$ appeared by two bands - a narrow intensive valent band absorption at $3260 \mathrm{~cm}^{-1}$ and deformation band at 1605 $\mathrm{cm}^{-1}$. In addition at $1240 \mathrm{~cm}^{-1}$ there is lea strip of valent vibration $\mathrm{C}-\mathrm{N}$ bond (Figure 2).
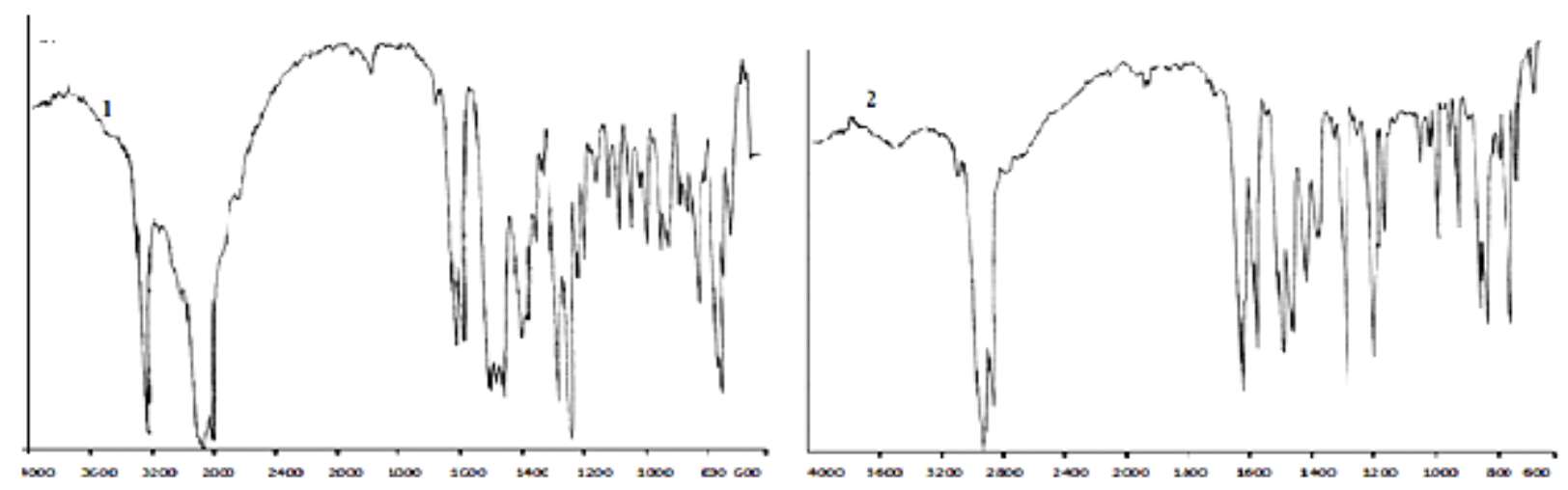

Fig. 2. IR spectra: 1 - restored $\mathrm{L}^{1} \mathrm{H}_{2}, 2$ - source $\mathrm{LH}_{2}$ Schiff base. 
In the IR spectrum of $\mathrm{Cu}$ (II) complex with $\mathrm{LH}_{2}$, the absorption band of the $\mathrm{C}=\mathrm{N}$ group is shifted toward low wave numbers and is observed at $1600 \mathrm{~cm}^{-1}$, which is noticeably smaller than the same band in the free ligand. A weak band at $3440 \mathrm{~cm}^{-1}$ can be attributed to hygroscopic water. The absorption band of phenolic hydroxyl is absent. These data indicate participation in the coordination of the azomethine nitrogen atom and oxygen atom of phenolic group. The data of elemental analysis and thermogravimetry indicate the molar ratio of metal ion: ligand is $1: 1$ and, accordingly, the composition $\left[\mathrm{Cu}_{2} \mathrm{~L}_{2}\right]$ (Figure 2). $\mathrm{Co}$ (II) and $\mathrm{Ni}$ (II) complexes have the similar structure with this ligand.

In the $\mathrm{Ni}(\mathrm{II})$ complex with a reduced Schiff base the band at $3275 \mathrm{~cm}^{-1}$, observed in the free $\mathrm{L}^{\prime} \mathrm{H}_{2}$ ligand, disappears and the bands at 3175 and $3400 \mathrm{~cm}^{-1}$ indicate participation of the amino group $\mathrm{NH}$ in coordination with the $\mathrm{Ni}$ (II) ion appears.

The IR spectrum of the $\mathrm{Cu}$ (II) complex with $\mathrm{L}^{\prime} \mathrm{H}_{2}$ in the region of $\mathrm{NH}$ vibrations contains a broadened band at $3150 \mathrm{~cm}^{-1}$, which can be attributed to coordinated $\mathrm{NH}$ group. The intensive narrow band at $3465 \mathrm{~cm}^{-1}$ may belong to hydroxyl group of the coordinated water molecule.

Magnetic moments and electronic spectra of the complexes. The electronic absorption spectrum of" ligand $\mathrm{L}^{\prime} \mathrm{H}_{2}$ in the UV region contains two absorption bands at 210 and $295 \mathrm{~nm}$. In the spectrum of the $\left[\mathrm{Cu}_{2} \mathrm{~L}^{\prime}\left(\mathrm{CH}_{3} \mathrm{COO}\right)_{2}\left(\mathrm{H}_{2} \mathrm{O}\right)_{2}\right]$ complex, in addition to the ligand bands, new absorption appear at 260 and $320 \mathrm{~nm}$ in UV and at 440, $460 \mathrm{~nm}$ in visible region and very weak band at $600 \mathrm{~nm}$. The magnetic moment of this complex is equal 1.8 B.m. The $\left[\mathrm{Co}_{2} \mathrm{~L}_{2}^{\prime}\right]$ complex shows a magnetic moment $\mu_{\mathrm{eff}}=4.8$ B.m, which to specify on the high-spin state $\mathrm{Co}(\mathrm{II})$ ion in this compound. In the electronic spectrum this complex, in addition to ligand bands, there is band at $280 \mathrm{~nm}$. In contrast to the copper and cobalt complexes, $\left[\mathrm{Zn}_{2} \mathrm{~L}_{2}^{\prime}\right]$ is diamagnetic, which undoubtedly indicates the square planar symmetry of this complex. There is full coincidence of the electronic spectra of cobalt and nickel complexes.

ESR spectra. The ESR spectrum of the $\left[\mathrm{Cu}_{2} \mathrm{~L}_{2}\right]$ copper complex in solid state has axial symmetry with two g-factor values: $\mathrm{g}_{\|}=2.34$, $\mathrm{g}_{\perp}=2.06$. An anisotropic hyperfine splitting on the $\mathrm{Cu}^{63,65}$ nucleus (nuclear spin 3/2) with the constant $\mathrm{A}_{\|}=0.185 \mathrm{~cm}^{-1}$ is also observed.

The $\left[\mathrm{Cu}_{2} \mathrm{~L}^{\prime}\left(\mathrm{CH}_{3} \mathrm{COO}\right)_{2}\left(\mathrm{H}_{2} \mathrm{O}\right)_{2}\right]$ complex also has spectrum characteristic of axial symmetry with g-factor values $\mathrm{g}_{\|}=2.51$ and $\mathrm{g}_{\perp}=$ 2.10. The axial character of the ESR spectra of the $\mathrm{Cu}_{2} \mathrm{~L}_{2}$ and $\left[\mathrm{CuL}^{\prime}\left(\mathrm{CH}_{3} \mathrm{COO}\right)\left(\mathrm{H}_{2} \mathrm{O}\right)\right]$ complexes, taking into account other data (elemental analysis, TGA, etc.), allows to accept the symmetry of the complexes, which is close to the square planar.

TGA. The thermal decomposition of discussed above complexes 1-4 was studied in the temperature range of $20-900^{\circ} \mathrm{C}$ with a heating rate of $20 \% \mathrm{~min}$. In Figure 3 shows the TG, DTG and DTA curves for the nickel complex.

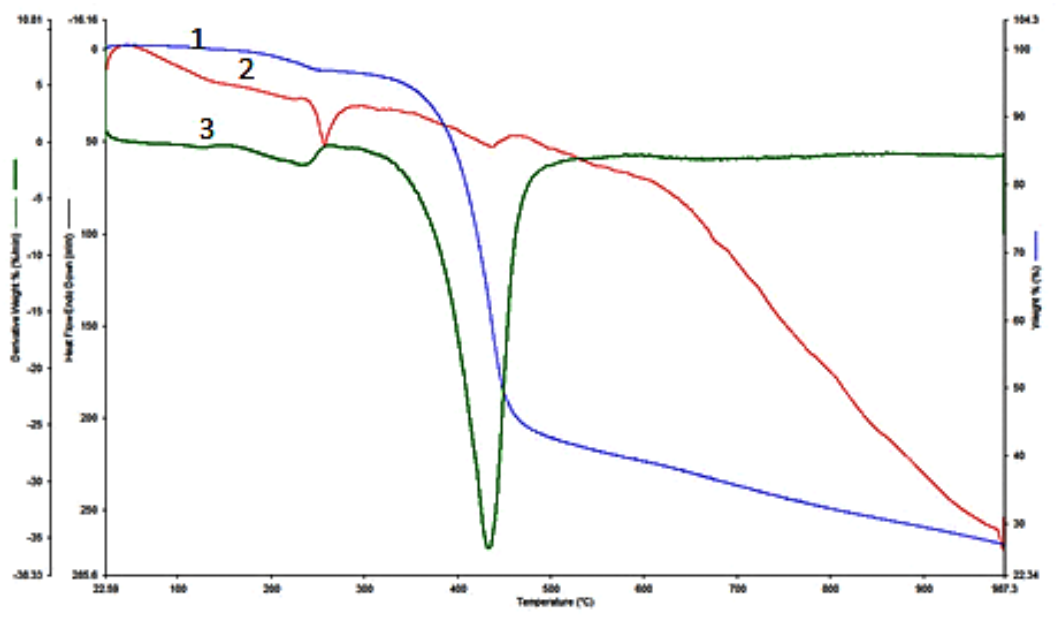

Fig. 3. Thermogram of $\left[\mathrm{Ni}_{2} \mathrm{~L}_{2}^{\prime}\right]$ complex. 1 - TG, 2 - DTG, 3 - DTA. 
Thermogravimetric analysis showed that the decomposition of compounds occurs in two stages. In the first stage, weight loss occurs in the temperature range of $150-350^{\circ} \mathrm{C}$ (depending on the nature of the metal ion), on the second stage, in the $400-600^{\circ} \mathrm{C}$ region, the final decomposition takes place to form the corresponding oxides. The amount of nickel oxides remaining after decomposition corresponds to the content of metals in the complexes, having the structure as in scheme.

The obtained data suggest the following structure for copper complexes with Schiff base $\mathrm{LH}_{2}$ and its reduced analogue $\mathrm{L}^{\prime} \mathrm{H}_{2}$ :

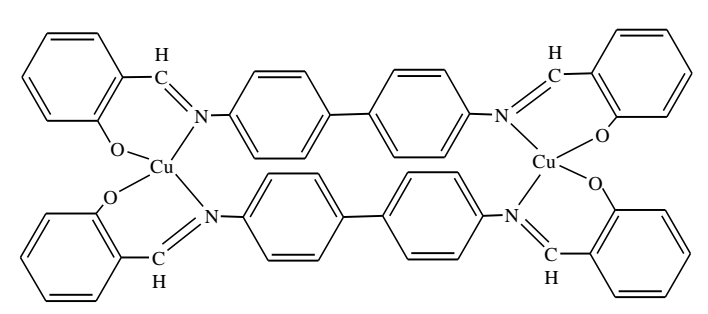

$\left[\mathrm{Cu}_{2} \mathrm{~L}_{2}\right]$

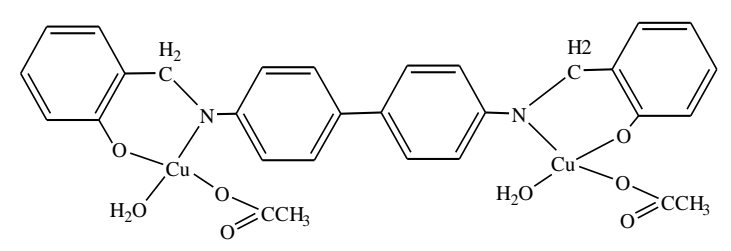

$\left[\mathrm{Cu}_{2} \mathrm{~L}^{\prime}\left(\mathrm{CH}_{3} \mathrm{COO}\right)_{2}\left(\mathrm{H}_{2} \mathrm{O}\right)_{2}\right]$

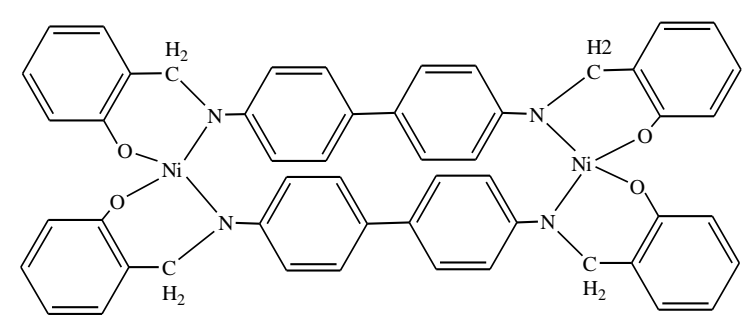

$\left[\mathrm{Ni}_{2} \mathrm{~L}_{2}^{\prime}\right]$

Diaminobenzidine derivatives are analogues of $p$-phenylenediamines and so must be redox-active, like $p$-phenylenediamine. The transition metal complexes with derivatives of diaminobenzidine, namely with reduced Schiff bases, as well as the initial ligands, capable to for- mate cation radicals at action one-electron oxidants. It is of interest to compare the stability of the formed cation radicals of ligand and their complexes, which can be obtained by action of bromine solution in acetic acid.

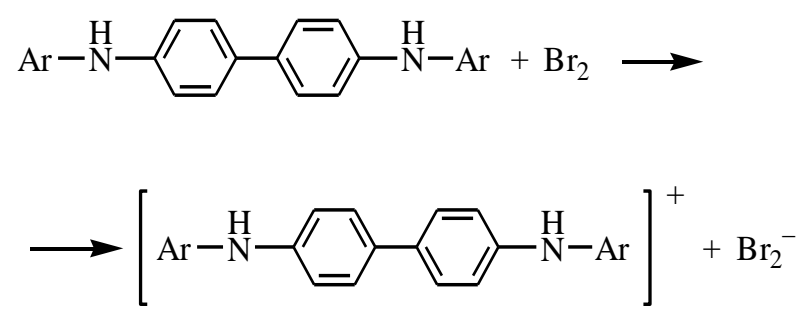<smiles>Oc1ccccc1C=[Al]</smiles>

It was found, that the cation radicals of disubstituted benzidine are much less stable in comparison with the cation radicals of $\mathrm{N}, \mathrm{N}^{\prime}$ disubstituted $p$-phenylenediamine. This likely due to significant disturbance of the conjugation between the nitrogen atoms in benzidine, owing to a possibility of rotation of benzene rings relatively each other. However, using electronic spectroscopy it is possible to observe the formation and decay of radicals. The absorption bands of the cation radical are observed at 470, 840 and $970 \mathrm{~nm}$. Destabilization of the $\left[\mathrm{ML}_{1}\right]^{+}$. cation radicals (where $\mathrm{M}$ is $\mathrm{Cu}$ (II), $\mathrm{Zn}$ (II)) may be caused the strong coulomb repulsion between positively charged radical cation and a metal ion. In Figure 4 shows the electronic spectra of the cation radicals $\mathrm{L}^{\prime} \mathrm{H}_{2}$ and $\left[\mathrm{Cu}_{2} \mathrm{~L}^{\prime}\left(\mathrm{CH}_{3} \mathrm{COO}\right)_{2}\left(\mathrm{H}_{2} \mathrm{O}\right)_{2}\right]^{+} \cdot$ as well as their decay during time. The comparison of these spectra shows that the rate of decay $\left[\mathrm{Cu}_{2} \mathrm{~L}^{\prime}\left(\mathrm{CH}_{3} \mathrm{COO}\right)_{2}\left(\mathrm{H}_{2} \mathrm{O}\right)_{2}\right]^{+}$' cation radicals is much higher than $\left[\mathrm{L}^{\prime} \mathrm{H}\right]^{+}$. Thus, the cation radicals $\left[\mathrm{Cu}_{2} \mathrm{~L}^{\prime}\left(\mathrm{CH}_{3} \mathrm{COO}\right)_{2}\left(\mathrm{H}_{2} \mathrm{O}\right)_{2}\right]^{+}$practically disappear within $\sim 6 \mathrm{~min}$, at that time a noticeable concentration of cation radicals $\left[\mathrm{L}^{\prime} \mathrm{H}\right]^{+}$are observed during $30 \mathrm{~min}$. 

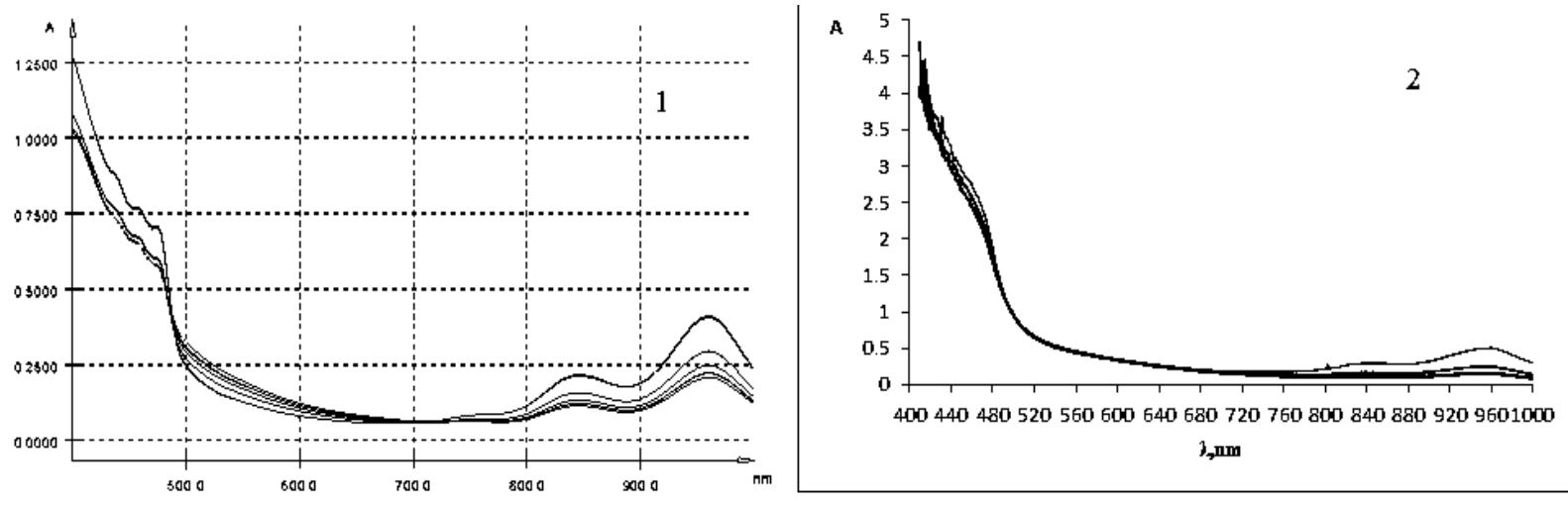

Fig. 4. Electronic absorption spectra of cation radicals formed by the action of a $\mathrm{Br}_{2}$ solution in acetic acid on the 1 - ligand $\mathrm{L}^{\prime} \mathrm{H}_{2}, 2$ - complex $\left[\mathrm{Cu}_{2} \mathrm{~L}^{\prime}\left(\mathrm{CH}_{3} \mathrm{COO}\right)_{2}\left(\mathrm{H}_{2} \mathrm{O}\right)_{2}\right]$.

\section{Conclusions}

Thus, the bis-(2-hydroxybenzyl)-benzidine formed with the $\mathrm{Co}(\mathrm{II}), \mathrm{Ni}(\mathrm{II}), \mathrm{Zn}$ (II) ions binuclear complexes of the composition $\left[\mathrm{M}_{2} \mathrm{~L}_{2}\right]$ and with $\mathrm{Cu}$ (II) a mixed ligand complex $\left[\mathrm{Cu}_{2} \mathrm{~L}^{\prime}\right.$ $\left.\left(\mathrm{CH}_{3} \mathrm{COO}\right)_{2}\left(\mathrm{H}_{2} \mathrm{O}\right)_{2}\right]$. It was shown that metal ion destabilizes cation radicals, which formed by action of an oxidizer(bromine).

\section{References}

1. Nassar A.M., Hassan A.M., Elkmash A.N. Synthesis, characterization, corrosion inhibition of mild steel in $\mathrm{HCl}(0.5 \mathrm{~N})$ solution and solid-state electrical conductivity of new $\mathrm{Co}(\mathrm{II}), \mathrm{Ni}(\mathrm{II})$, $\mathrm{Cu}(\mathrm{II})$ and $\mathrm{Zn}$ (II) complexes. Appl. Organometal. Chem. 2016. No 31(3). P. 1-9.

2. Vigato P.A., Tamburini S. Advances in acyclic compartmental ligands and related complexes. Coord Chem. Rev. 2008. No 252. P. 1871-995.

3. Park S., Mathur V.K., Planalp R.P. Syntheses, solubilities and oxygen absorption properties of new cobalt(II) Schiff-base complexes. Polyhedron. 1998. No 17. P. 325-330.

4. Lee N.H., Byun J.C., Baik J.S., Han C-H, Han Sb. Development of $\mathrm{Mn}$ (III) (Schiff Base) complexes for the catalyst of olefin oxygenation to alcohols in the presence of $\mathrm{NaBH}_{4}$. Bull Korean Chem. Soc. 2002. No 23. P. 1365-1366.

5. Mardani H.R., Golchoubian H. Selective and efficient $\mathrm{C}-\mathrm{H}$ oxidation of alkanes with hydrogen peroxide catalyzed by a manganese( III) Schiff base complex. J. Mol. Cat. A. Chem. 2006. No 259. P. 197-200.

6. Kwiatkowski E., Romanowski G., Nowicki W., Kwiatkowski M., Suwin'ska K. Chiral dioxovana$\operatorname{dium}(\mathrm{V})$ complexes with single condensation products of 1,2-diaminocyclohexane and aromatic o-hydroxycarbonyl compounds: synthesis, charac- terization, catalytic properties and structure. Polyhedron. 2007. No 26. P. 2559-68.

7. Maurya M.R., Chandrakar A.K., Chand S. Zeolite$\mathrm{Y}$ encapsulated metal complexes of oxovanadium(VI), copper(II) and nickel(II) as catalyst for the oxidation of styrene, cyclohexane and methyl phenyl sulfide. J. Mol. Cat. A. Chem. 2007. No 274. P. 192-201.

8. Ourari A., Baameur L., Khan M.A., Bouet G. Is the electrocatalytic epoxidation of stilbene isomers using manganese (III) tetradentate Schiff bases complexes stereoselective. Electrochem Commun. 2008. No 10. P. 1736-1739.

9. Roy P., Nandi M., Manassero M., Ricco' M., Mazzani M., Bhaumik A., Banerjee P. Four 14oxo-bridged copper(II) complexes: magnetic properties and catalytic applications in liquid phase partial oxidation reactions. Dalton Trans. 2009. No 43. P. 9543-54.

10. Ourari A., Khelafi M., Aggoun D., Bouet G., Khan M.A. Synthesis, characterization, and electrochemical study of tetradentate ruthenium-Schiff base complexes: dioxygen activation with a cytochrome P450 model using 1- or 2-methylimidazole as axial bases. Adv. Phys. Chem. 2011. doi:10.1155/2011/157484.

11. Gupta K.C., Sutar A.K.. Catalytic activities of Schiff base transition metal complexes. Coord Chem Rev. 2008. No 252. P. 1420-50.

12. Krishnaraj S., Muthukumar M., Viswanathamurthi P., Sivakumar S. Studies on ruthenium(II) Schiff base complexes as catalysts for transfer hydrogenation reactions. Trans Met Chem. 2008. No 33. P. 643-8.

13. Burrows C.J., Muller J.G., Poulter G.T., Rokita S.E. Nickel-catalyzed oxidations: from hydrocarbons to DNA. Acta Chem Scand. 1996. No 50. P. 337-44.

14. Firdausa F., Fatmaa K., Azama M., Khanb S.N., Khanb A.U., Shakir M. Template synthesis and physico-chemical characterization of Synthesis and characterisation of $\mathrm{Co}(\mathrm{II}), \mathrm{Ni}(\mathrm{II}), \mathrm{Zn}(\mathrm{II})$ and 
$\mathrm{Cd}(\mathrm{II})$ complexes 14-membered tetraimine macrocyclic complexes, [MLX2] [M=Co(II), Ni(II), $\mathrm{Cu}(\mathrm{II})$ and $\mathrm{Zn}(\mathrm{II})]$. DNA binding study on [CoLCl2] complex. Spectrochim Acta Part A. 2009. No 72. P. 591-96.

15. Shakira M., Azama M., Parveena S., Khanb A.U., Firdaus F. Synthesis and spectroscopic studies on complexes of N,N0-bis-(2-pyridinecarboxaldimine)1,8-diaminonaphthalene (L); DNA binding studies on $\mathrm{Cu}(\mathrm{II})$ complex. Spectrochim Acta Part A. 2009. No 71. P. 1851-6.

16. Shakir M., Khanam S., Azam M., Aatif M., Firdaus F. Template synthesis and spectroscopic characterization of 16-membered [N4] Schiff-base macrocyclic complexes of $\mathrm{Co}(\mathrm{II}), \mathrm{Ni}(\mathrm{II}), \mathrm{Cu}(\mathrm{II})$, and $\mathrm{Zn}(\mathrm{II})$ : in vitro DNA-binding studies. J. Coord. Chem. 2011. No 64. P. 3158-68.

17. Ourari A., Ouari K., Khan M.A., Bouet G. Dioxygen activation with a cytochrome P450 model characterization and electrochemical study of new unsymmetrical tetradentate Schiff-base complexes with iron(III) and cobalt(II). J. Coord. Chem. 2008. No 61. P. 3846-59.

18. Nakamura T., Niwa K., Fujiwara M., Matsushita T. Novel dinuclear manganese(III) complexes with tridentate and bridging tetradentate Schiff base ligands: preparation. properties and catalaselike function. Chem. Lett. 1999. No 10. P. 1067-8.

19. Dede B., Karipcin F., Cengiz M. Novel homo- and hetero-nuclear copper(II) complexes of tetradentate Schiff bases: synthesis, characterization, solvent-extraction and catalase-like activity studies. J. Hazard. Mat. 2009. No 163. P. 1148-56.

20. Halcrow MA, Christou G. Biomimetic chemistry of nickel. Chem Rev. 1994. No 94. P. 2421-81.

21. Zeyad A. Saleh, Dhaidan Kh. Kafi. Synthesis and Spectroscopic Characterization for bis-(salysylaldehyde) Benzidine. Physical Chemistry 2016. V. 6. No 2. P. 49-56.

\section{N,N'-bis-(2-HİDROKSİBENZIL)-BENZİİNIN CO(II), NI(II), ZN(II) Və CU(II) KOMPLEKSLəRİ S.Z.İsmayılova}

Salisilaldehid və benzidinin 2:1 mol nisbətində kondensasiyası ilə sintez edilmiş və müvafiq olaraq natriumborhidridlə hidrogenləşdirilmiş Şiff əsası ilə $\mathrm{Co}(\mathrm{II}), \mathrm{Ni}(\mathrm{II}), \mathrm{Zn}$ (II) və $\mathrm{Cu}$ (II) keçid metallarının yeni ikinüvəli kompleksləri sintez edilmişdir. Sintez edilmiş komplekslərin quruluş və xassələri element analizi, İQ və elektron spektroskopiya, həmçinin derivatoqrafiya metodları ilə öyrənilib.

Açar sözlor: salisil aldehid, benzidin, Şiff asası, metal komplekslor.

\section{КОМПЛЕКСЫ СО(II), NI(II), ZN(II) И СU(II) N,N'-бис-(2-ГИДРОКСИБЕНЗИЛ)-БЕНЗИДИНОМ}

\section{С.З.Исмаилова}

Синтезированы новые биядерные комплексы $\mathrm{Co}(\mathrm{II}), \mathrm{Ni}(\mathrm{II}), \mathrm{Zn}$ (II) и $\mathrm{Cu}(\mathrm{II})$ с восстановленным Шиффовым основанием, полученным путем конденсации салицилальдегида и бензидина, при мольном отношении 2:1, с последующим восстановлением боргидридом натрия. Состав и строение полученных комплексов изучены методами элементного анализа, ИК- и электронной спектроскопии, а также дериватографически.

Ключевые слова: салицилальдегид, бензидин, основание Шиффа, комплексы металла. 